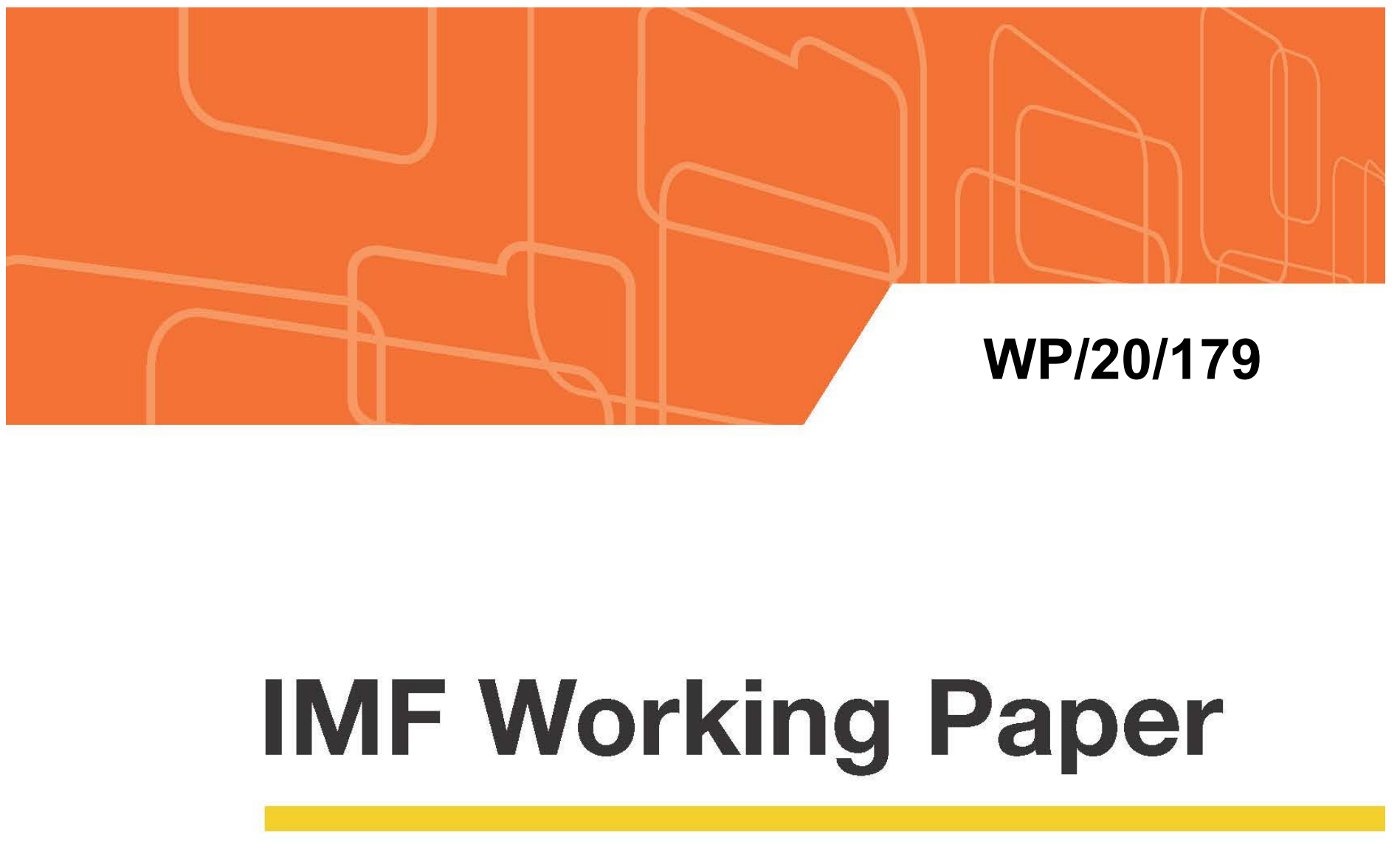

\title{
Offshore Currency Markets: Non-Deliverable Forwards (NDFs) in Asia
}

\author{
by Jochen M. Schmittmann and Chua Han Teng
}

IMF Working Papers describe research in progress by the author(s) and are published to elicit comments and to encourage debate. The views expressed in IMF Working Papers are those of the author(s) and do not necessarily represent the views of the IMF, its Executive Board, or IMF management.

$$
\text { I N TER N A T | O N A L M O N E T A R Y F U N D }
$$




\title{
IMF Working Paper
}

\section{Asia and Pacific Department}

\author{
Offshore Currency Markets: Non-Deliverable Forwards (NDFs) in Asia \\ Prepared by Jochen M. Schmittmann and Chua Han Teng \\ Authorized for distribution by Nada Choueiri
}

September 2020

IMF Working Papers describe research in progress by the author(s) and are published to elicit comments and to encourage debate. The views expressed in IMF Working Papers are those of the author(s) and do not necessarily represent the views of the IMF, its Executive Board, or IMF management.

\begin{abstract}
Non-deliverable forward (NDF) markets in many Asian emerging market currencies are large, rapidly growing, and often exceed onshore markets in transaction volume. NDFs tend to price significant depreciation during market stress episodes including COVID-19. Spillovers from NDFs to onshore markets are a policymaker concern. Our analysis shows that influences tend to run both ways after controlling for differences in timezones between markets. For the COVID-19 pandemic there is some evidence of NDFs leading onshore markets for a few currencies. Policy approaches to NDFs vary widely across Asia from close integration with onshore markets to severe restrictions on NDF trading.
\end{abstract}

JEL Classification Numbers: F31, G12, G13, G15

Keywords: Currency Markets; Offshore Markets; Non-Deliverable Forwards; NDF; DNDF Author’s E-Mail Address: jschmittmann@imf.org; hchua@imf.org 


\section{Contents}

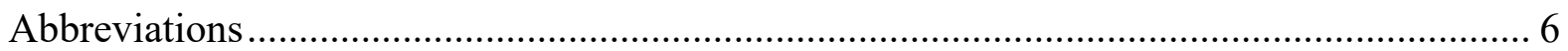

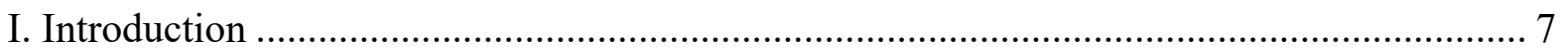

II. The Size of NDF Markets in Asian Currencies.............................................................. 9

III. Policy Approaches to NDF Markets ............................................................................. 11

IV. Volatility and Pricing of Onshore Forwards and Offshore NDFs .............................. 13

V. Price Linkages Between Onshore and Offshore Currency Markets .............................. 17

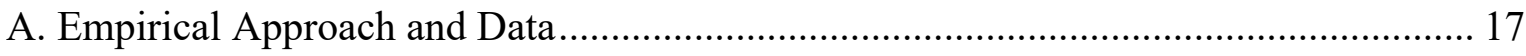

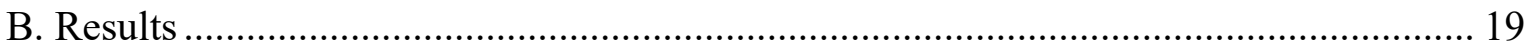

C. Price Linkages During the COVID-19 Pandemic .................................................... 20

VI. Domestic Non-Deliverable Forwards (DNDFs) .......................................................... 21

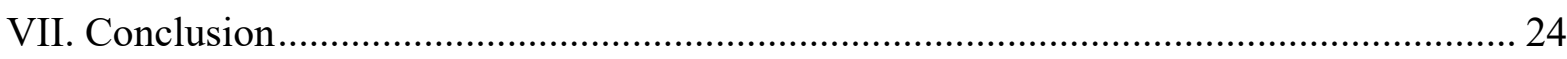

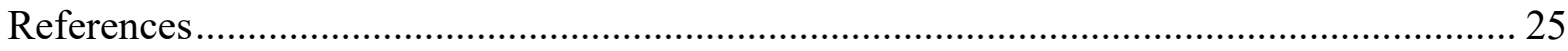

Appendix 1: Realized volatility of onshore forwards and NDFs.................................... 27

Appendix 2: Coefficients and intercepts for the long-run cointegration regressions ............ 27

Appendix 3: Coefficients on error correction terms; daily data ......................................... 28

Appendix 4: Coefficients on error correction terms; hourly data ....................................... 28

\section{Figures}

Figure 1. BIS Survey: NDF Daily Transaction Volumes of Asian Currencies .................... 10

Figure 2. BIS Survey: Daily Transaction Volumes by FX Instrument............................... 10

Figure 3. NDF Average Daily Turnover in London ................................................... 10

Figure 4. NDF Average Daily Turnover in Tokyo ........................................................ 10

Figure 5. Indonesia monthly FX Market Turnover........................................................ 11

Figure 6. Malaysia monthly FX Market Turnover........................................................ 11

Figure 7. Chinese Yuan Market Turnover ..................................................................... 13

Figure 8. Asian FX 1-Month Realized Volatility ........................................................... 14

Figure 9. Onshore Forward Less Offshore NDF Implied Yields....................................... 14

Figure 10. Korean won Onshore Forward Less Offshore NDF Implied Yield .................... 16

Figure 11. New Taiwan dollar Onshore Forward Less Offshore NDF Implied Yield .......... 16

Figure 12. Indonesian Rupiah Onshore Forward Less Offshore NDF Implied Yield........... 16 
Figure 13. Indian Rupee Onshore Forward Less Offshore NDF Implied Yield................... 16

Figure 14. Malaysian Ringgit Onshore Forward Less Offshore NDF Implied Yield ........... 16

Figure 15. Philippine Peso Onshore Forward Less Offshore NDF Implied Yield ................ 16

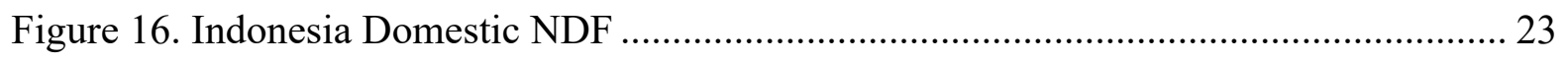

Figure 17. Indonesia Domestic and Offshore NDF .................................................... 23

Figure 18. IDR forward curves on 27 Dec 2019........................................................ 23

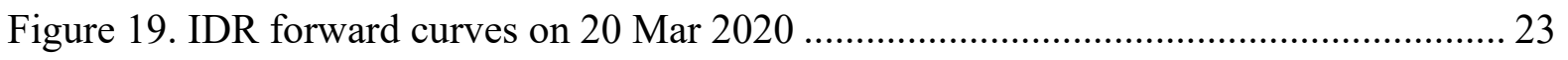

\section{Tables}

Table 1. Granger Causality Tests for NDFs at New York Close....................................... 20

Table 2. Granger Causality Tests for NDFs at Asia Trading Hours .................................. 20

Table 3. Granger Causality Tests During COVID-19 ...................................................... 21 


\begin{tabular}{|c|c|}
\hline & Abbreviations \\
\hline ADF & Augmented Dickey-Fuller \\
\hline $\mathrm{BI}$ & Bank Indonesia; Indonesia's central bank \\
\hline BIS & Bank for International Settlements \\
\hline BNM & Bank Negara Malaysia; Malaysia's central bank \\
\hline BSP & Bangko Sentral ng Pilipinas; Philippines' central bank \\
\hline CIP & Covered Interest Rate Parity \\
\hline CRRP & Currency Rate Risk Protection Program \\
\hline DNDF & Domestic Non-deliverable Forward \\
\hline DTCC & Depository Trust \& Clearing Corporation \\
\hline ECT & Error Correction Term \\
\hline EM & Emerging Market \\
\hline IMF & International Monetary Fund \\
\hline NDF & Non-deliverable Forward \\
\hline OTC & Over-the-counter \\
\hline RBI & Reserve Bank of India; India's central bank \\
\hline SIC & Schwarz' Bayesian Information Criterion \\
\hline Taiwan POC & Taiwan Province of China \\
\hline VECM & Vector Error Correction Model \\
\hline \multicolumn{2}{|c|}{ Currency abbreviations: } \\
\hline $\mathrm{CNH}$ & Offshore Chinese yuan \\
\hline CNY & Chinese yuan \\
\hline IDR & Indonesian rupiah \\
\hline INR & Indian rupee \\
\hline KRW & Korean won \\
\hline MYR & Malaysian ringgit \\
\hline PHP & Phillipine peso \\
\hline THB & Thai baht \\
\hline TWD & New Taiwan dollar \\
\hline USD & US dollar \\
\hline
\end{tabular}




\section{INTRODUCTION ${ }^{1}$}

Non-deliverable forward (NDF) markets in many Asian emerging market currencies are large, rapidly growing, and often exceed onshore markets in transaction volume. Policymakers pay close attention to NDF markets recognizing potential implications for financial stability and onshore financial markets. The wide spectrum of policy approaches to NDFs across Asia highlights policy tradeoffs. This paper provides a comprehensive and current overview of Asian NDF market developments, discusses policy approaches, and analyzes the direction of influence between NDFs and onshore currency markets.

NDFs are foreign exchange forward contracts that do not require physical delivery of the underlying currencies. Transactions are cash-settled, typically in US dollar, through net payments that are equivalent to the difference between the spot rate at the maturity date and the previously agreed forward rate. NDFs trade over-the-counter, rather than on exchanges, in major financial centers outside the jurisdiction of the authorities of the corresponding currencies. $^{2}$

NDF markets developed in response to restrictions that constrained access to onshore markets. Despite significant financial account liberalization across Asia, most Asian emerging market currencies are only partially convertible and not deliverable offshore. Restrictions take many forms including requirements on underlying asset exposure for currency positions. For investors, banks, and corporates, NDF markets are often an attractive alternative to onshore markets due to the absence of regulation, longer trading hours, reduced documentation requirements, often good liquidity, no convertibility risk, and reduced credit risk because of net settlement.

Asia accounts for the most traded NDF currencies worldwide, with the largest volumes in the Korean won (KRW), Indian rupee (INR), and New Taiwan dollar (TWD). For these currencies, NDF volumes exceed turnover in other foreign exchange products including spot transactions. In Asia, sizeable NDF markets also exist for the Chinese yuan (CNY) and the Indonesian rupiah (IDR), and to a lesser extent for the Malaysian ringgit (MYR), Philippine peso (PHP), and Vietnamese dong. Section II describes the size of NDF markets in Asian currencies.

NDF markets' large size, volatility, and pricing differentials relative to onshore markets have raised concerns over spillovers from the offshore to the onshore market. Policymakers' ability

\footnotetext{
${ }^{1}$ We thank Reda Cherif, Nada Choueiri, Dimitris Drakopoulos, Anna Ilyina, Rajeev de Mello, and Evan Papageorgiou for helpful comments and Elise Toh for help with word processing.

${ }^{2}$ London accounts for close to half of all trading (45\%), followed by the US (16\%), Singapore (16\%), and Hong Kong SAR (12\%) (Patel \& Xia 2019).
} 
to monitor and regulate trading in offshore NDF markets is limited. ${ }^{3}$ As a result, exchange rate management could be less effective, reducing the ability to conduct an independent monetary policy. A potential destabilizing influence from NDFs to onshore markets is a further concern, particularly during times of stress. Such spillovers are not limited to onshore currency markets. For example, when hedging costs using NDFs become very expensive-we show in section IV that this is the case in crisis periods-it can lead international investors to liquidate local currency bond holdings. ${ }^{4}$ Additional policymaker concerns are market fragmentation and a loss of revenue for domestic financial institutions.

Policy approaches to NDF markets vary across Asia. Some countries, notably Korea, maintain few restrictions on onshore financial institutions' participation in the NDF market, resulting in close integration between offshore and onshore markets. Other countries retain more restrictions, with Malaysia taking some of the strongest policy measures to limit ringgit trading to onshore markets. Indonesia introduced a domestic version of NDFs (DNDFs), settled in local currency, as an alternative to USD-settled offshore NDFs. Section III surveys the range of policy approaches to NDF markets in Asia and section VI discusses DNDFs.

The question of pricing relationships between NDFs and onshore FX markets is an empirical one. ${ }^{5}$ In section $\mathrm{V}$, we analyze pricing relations for the Asian currencies with the most important NDF markets, the IDR, INR, KRW, MYR, PHP, and TWD. ${ }^{6}$ We employ a vector error correction approach to analyze the equilibrium and the lead-lag relationships between markets. We innovate by exactly time-matching NDF and onshore price quotes, unlike most of the existing literature which uses end-of-day quotes across time zones. We show that this is crucial-with the traditional approach of using price quotes at different times of the day we find that influences tend to be from NDFs to onshore markets, but with careful time-matching of quotes, influences tend to run in both directions consistent with price discovery in onshore and offshore markets. For the COVID-19 pandemic period, we find some evidence for an increased influence of NDFs on onshore markets for a few currencies.

The literature on NDF markets in Asia is limited. Most studies focus on individual currencies and are dated. McCauley, Shu, and Ma (2014), McCauley and Shu (2016) and Reserve Bank of India (2019) provide comprehensive overviews of NDF markets. Recent spillover studies

\footnotetext{
${ }^{3}$ Policymakers can impose limits on domestic actors' involvement in NDF markets. They can also attempt to forbid facilitation of NDF transactions by foreigners through attestations of non-participation in the market as a precondition for domestic market access.

${ }^{4}$ Market contacts pointed out the link between hedging costs and bond holdings. Empirically, hedge costs and flows into local currency bonds are correlated, but many factors including global risk aversion are driving this correlation.

${ }^{5}$ Directional influence in this paper refers to an asset price significantly affecting another asset price in the sense of Granger (1969). See section V for technical details.

${ }^{6}$ We do not include $\mathrm{CNY}$ in the analysis given that the offshore Chinese yuan $(\mathrm{CNH})$ market is increasingly replacing CNY NDF trading as discussed in section III.
} 
include McCauley, Shu, and Ma (2014) for major currencies and Reserve Bank of India (2019) for INR. We contribute to the literature with a comprehensive and fresh look at Asian currency NDFs that considers recent developments including DNDFs and the COVID-19 pandemic. Our analysis of the direction of influence between NDF and onshore FX markets provides new insights by differentiating between time-zone induced and concurrent spillovers. Our findings help to explain the mixed results in the literature.

\section{The Size of NDF MARKets IN ASIAN CURRENCIES}

Turnover data for NDFs is mostly available from surveys, given the over-the-counter nature of NDF trading. A shift to centralized trading and clearing in recent years (McCauley and Shu 2016) also made data from clearing and settlement service providers available. Data sources vary in coverage and frequency but the relative importance of currencies across sources is broadly consistent. Data on the investor base for NDF markets is not available, but it is thought to mainly comprise multinational corporations, portfolio investors, hedge funds and proprietary foreign exchange accounts of commercial and investment banks ( $\mathrm{Ma}, \mathrm{Ho}$, and McCauley 2004).

The Bank for International Settlements (BIS) Triennial Central Bank Survey provides the most comprehensive information about the size and structure of global NDF markets but is only available on a triennial basis and for a limited number of currencies (in Asia: CNY, INR, KRW, TWD). ${ }^{7}$ Major trading centers for NDFs publish surveys of trading activity in their jurisdiction with varying coverage and frequency-we present data from London and Tokyo below. The Depository Trust \& Clearing Corporation (DTCC), a clearing and settlement services provider, provides data on NDF trades on its systems. We present DTCC and authorities' data below to cover IDR and MYR which are not included in the currency breakdown of the BIS survey.

Asia accounts for three of the top four NDF currencies by volume globally according to the BIS survey. The INR, KRW, and TWD accounted for $55 \%$ of total daily global NDF turnover of USD258 bn as of April 2019 (Figure 1). The CNY accounts for another 5\% of global NDF turnover. Outside of Asia, the Brazilian real (14\%) and the Russian ruble (2\%) have sizeable NDF markets. NDF trading in INR, TWD, and KRW experienced the fastest growth since 2016, rising $204 \%, 168 \%$, and $100 \%$, respectively.

Relative to other foreign exchange products—spot, outright forwards, swaps, options-NDF trading volumes are large for INR, KRW, and TWD (Figure 2). For these currencies, NDF volumes far exceed all other FX products including spot trading. This underscores the importance of NDF markets for price discovery and relevance from policymakers' perspective.

\footnotetext{
${ }^{7}$ In addition to CNY, INR, KRW, and TWD for which NDF markets exist, the BIS reports data on other FX instruments for these Asian currencies: AUD, HKD, JPY, NZD, SGD.
} 
Daily NDF trading in three Asian currencies (INR, KRW, TWD) accounts for 55\% of global NDF trading volume.

Figure 1. BIS Survey: NDF Daily Transaction Volumes of Asian Currencies

(Billions of US Dollars and Percent)

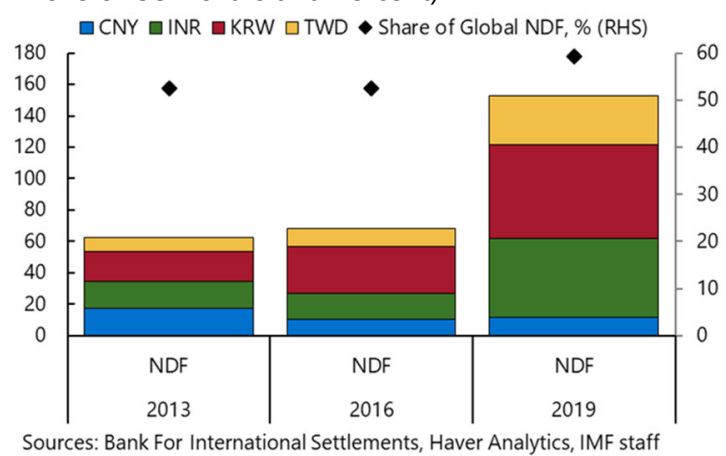

NDFs account for the largest share of trading by instrument for INR, KRW, and TWD.

Figure 2. BIS Survey: Daily Transaction Volumes by FX Instrument

(Billions of US Dollars)

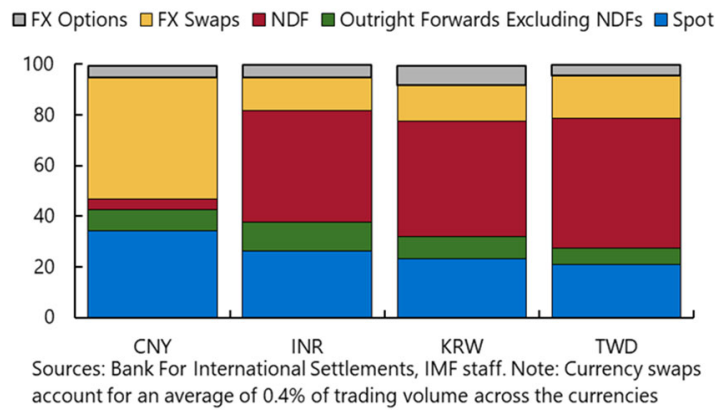

Bank of England NDF volume data for London, the world's largest NDF trading hub, is broadly in line with BIS data (Figure 3). The KRW and INR are the most widely traded NDFs in London. In Tokyo, an important NDF trading hub in Asia, the KRW, INR, TWD, and IDR are the most widely traded NDF currencies (Figure 4).

$K R W$ and INR are the most widely traded NDFs in London, the world's largest market for NDFs.

Figure 3. NDF Average Daily Turnover in London (Millions of US Dollars)

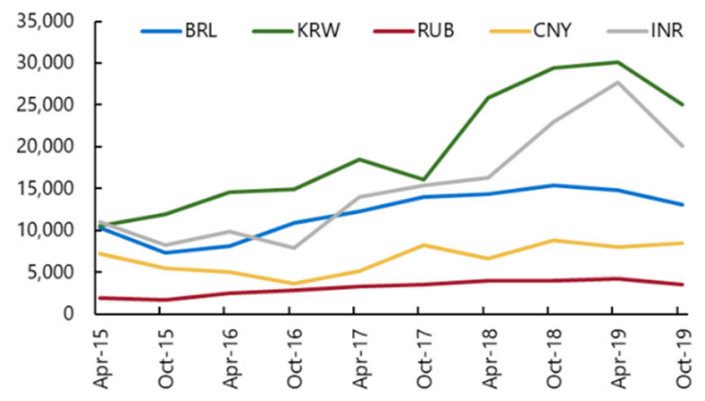

Source: Bank of England
In Tokyo, an important regional hub for NDFs, KRW and INR are also the most traded currencies, followed by IDR and TWD.

Figure 4. NDF Average Daily Turnover in Tokyo (Millions of US Dollars)

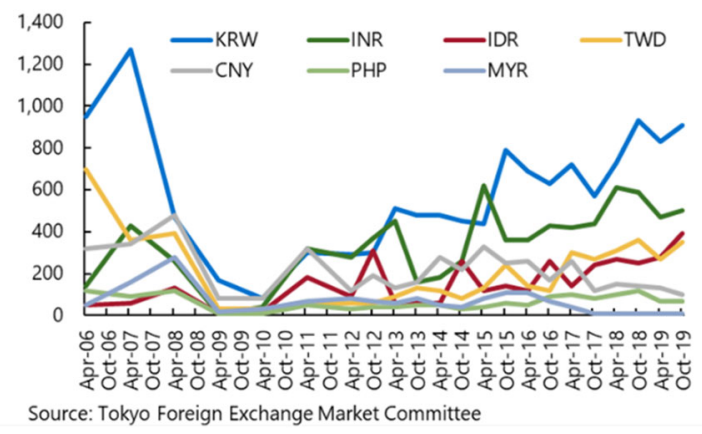

Among South East Asian currencies, the IDR is the most traded NDF. IDR monthly NDF turnover exceeds USD100 bn based on DTCC data, more than spot and onshore deliverable forward transaction volumes combined (Figure 5). ${ }^{8}$ The MYR boasted a large NDF market until Bank Negara Malaysia reinforced a ban on offshore NDF trading in November 2016 (Figure 6). There is no Thai baht offshore NDF market due to the presence of an offshore deliverable

${ }^{8}$ DTCC data likely substantially understates total NDF trading. For currencies where both DTCC and BIS data is available, BIS data is larger by a factor of 2 to 4 . 
forward market. ${ }^{9}$ Philippine peso NDF volumes are small, reflecting the relatively small foreign participation in local asset markets and shallow financial markets in general.

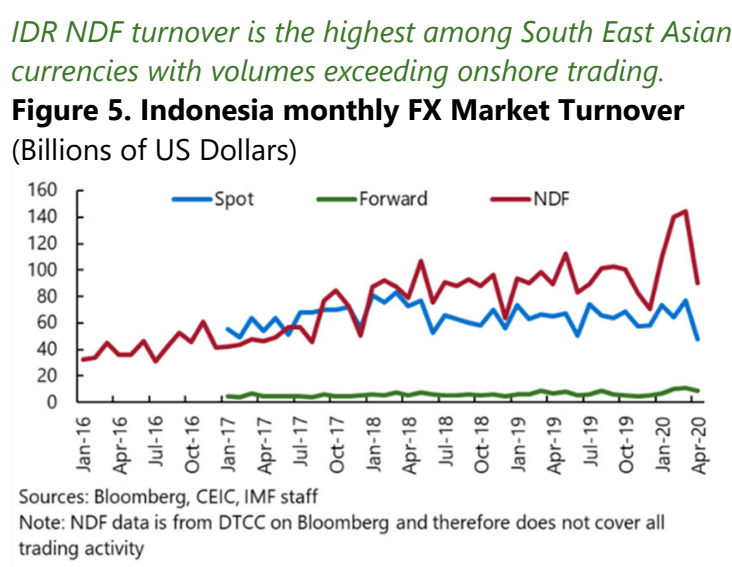
MYR NDF activity dropped sharply after the authorities
reinforced a ban on NDF trading.

Figure 6. Malaysia monthly FX Market Turnover (Billions of US Dollars)

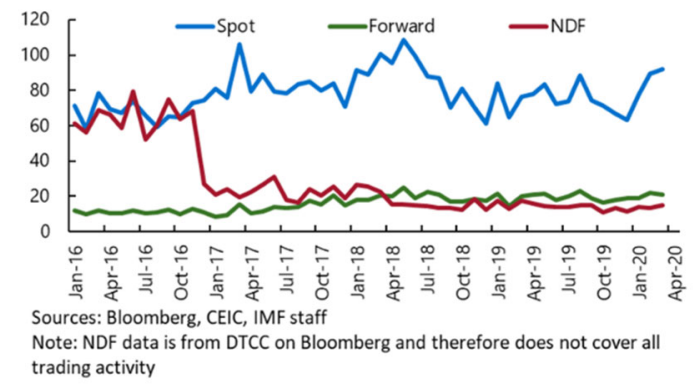

\section{Policy Approaches to NDF MARKets}

NDF markets exist because of currency non-deliverability offshore and restrictions in onshore markets particularly for nonresidents. Such restrictions are present in most emerging markets. They take various forms including underlying asset requirements for currency positions, restrictions on participants in currency markets, prudential and documentation requirements, and regulation on permissible foreign exchange products. The motivation behind these restrictions is to safeguard financial stability, curb financial speculation and maintain control over the currency onshore.

Do NDFs disappear when a country moves its currency to full convertibility? ${ }^{10}$ Not necessarily. Factors besides restrictions in onshore markets matter as well. Convenient trading hours and good liquidity make NDFs attractive. In crisis episodes, convertibility risk ${ }^{11}$ can be a consideration in favor of NDFs. The Russian ruble was made fully convertible in 2006, yet an active NDF market with a daily turnover of USD5.5 bn still exists as of 2019. A factor for the continued relevance of the ruble NDF market could be credit and legal concerns related to the enforceability of collateral arrangements and sanctions (McCauley and Shu 2016).

Against this backdrop, countries in Asia have made different choices in their approach to NDF markets. Korea has a generally open capital account but maintains limits on non-resident KRW borrowing from banks in Korea and registration requirements for non-resident portfolio

\footnotetext{
${ }^{9}$ Historically, the Bank of Thailand also enforced a ban on NDF quotation by international banks that had business activity in Thailand, similar to Bank Negara Malaysia.

${ }^{10}$ Convertibility is the ease with which a currency can be converted into another currency.

${ }^{11}$ Convertibility risk refers to the risk of loss arising from an inability to convert local currency into a fully convertible currency and/or to repatriate convertible currency back to a home country as a result of exchange controls.
} 
investors. Korean onshore investors can freely participate in the NDF market. As a result, arbitrage ensures close integration between onshore and offshore markets (see section IV). The embrace of NDFs has made the KRW the world's largest and most liquid NDF market with daily turnover around USD 60bn according to the BIS. For the TWD-another major NDF currency - there is partial integration between onshore and NDF markets as Taiwanese banks can participate in the NDF market up to $20 \%$ of their net open FX positions. Taiwan POC also maintains limits on non-resident investment in local currency bonds and has onshore currency transaction reporting requirements.

In contrast to Korea and Taiwan POC, Malaysia took a different approach aimed at developing onshore FX markets while seeking to curtail MYR activity in offshore markets (IMF 2019). In November 2016 Bank Negara Malaysia (BNM) enforced a requirement for banks to attest that they do not engage or facilitate transactions in the offshore ringgit NDF market. ${ }^{12}$ The measure was related to concerns over speculative activity in the NDF market. Most international banks complied and as a result activity in the MYR NDF market dropped significantly (Figure 6). Initially, onshore FX volumes increased only marginally. Some international investors liquidated holdings of Malaysian bonds. ${ }^{13}$ Subsequently, steps were taken to deepen onshore FX markets including more convenient access for non-resident investors, simplified procedures, and relaxation of underlying asset requirements for FX positions (IMF 2020). ${ }^{14}$ Partly as a result of these initiatives, onshore FX market turnover increased. The sum of turnover in onshore markets and NDFs remains substantially below levels before November 2016, indicating that not all activity that disappeared from NDF markets migrated to onshore markets. ${ }^{15}$

The IDR has the largest NDF market among South East Asian currencies. The size of the IDR NDF market is a function of strong global investor interest in the local bond market-foreign participation is among the highest in Asia-and restrictions on non-resident currency positions onshore without underlying assets. In 2018, Bank Indonesia introduced a domestic NDF (DNDF) settled on a net basis in IDR (instead of USD for the offshore NDF) to deepen the onshore market. As of May 2020, the DNDF is primarily a monetary policy tool for Bank

\footnotetext{
12 The requirement not to engage in the NDF market was longstanding but not strictly enforced. In November 2016, BNM required an attestation from banks to certify that they did not engage in the NDF market. In December 2016, BNM introduced a requirement for conversion of 75 percent of export proceeds into MYR and a measure limiting investment in FX assets by residents with domestic ringgit borrowing was extended to exporters.

${ }^{13}$ Some market participants indicated a preference for NDFs at the time due to convenience. Restrictions on currency positions without underlying asset exposures in onshore markets were an additional concern.

${ }^{14}$ Since April 2017 registered nonresident investors are allowed to hedge up to 100 percent of their MYR exposures, up from 25 percent, and take additional 25 percent MYR exposure on top of their underlying asset.

15 This is unsurprising since a large share of trading in NDFs is without underlying asset positions which is not permissible in the Malaysian onshore market.
} 
Indonesia with limited secondary market activity and non-resident participation. We discuss the DNDF in detail in section VI.

The Chinese yuan is another unique case. Through capital controls the market is segmented into a tightly controlled onshore market (CNY) and an offshore market without restrictions $(\mathrm{CNH})$. There are three different forward markets: onshore deliverable (CNY) accessible mostly to residents; offshore NDF (CNY NDF); and offshore deliverable (CNH). The CNY NDF market in place since the 1990s has been gradually replaced by the offshore deliverable forward $(\mathrm{CNH})$ market, which was created in 2010 (Figure 7).
Chinese yuan NDF activity dropped amid the rise of the offshore deliverable forward market (CNH).

Figure 7. Chinese Yuan Market Turnover

(Average Daily Turnover; Billions of US Dollars)

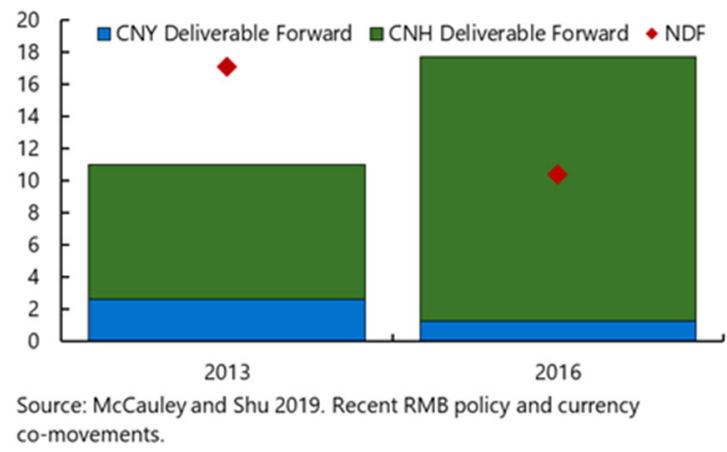

In India, the fast growth of the INR NDF market raised concerns around the forces determining the currency value and the authorities' ability to ensure currency stability (Reserve Bank of India, 2019). The Reserve Bank of India commissioned a Task Force to study the offshore INR market. The commission recommended steps to develop the onshore FX market including longer trading hours, new FX products, some liberalization of underlying asset requirements for FX positions, and other market development steps. The Reserve Bank of India allowed onshore banks to participate in the NDF market from June 2020.

\section{Volatility ANd Pricing of Onshore ForWARds ANd OFFshore NDFs}

The volatility and pricing of NDFs relative to onshore FX markets provides insight in the behavior of both markets and the interactions between them. High volatility does not necessarily indicate a more speculative investor base or price overshooting. It would also be consistent with the absence of policy intervention or faster price discovery. Similarly, a comparison of pricing between onshore and offshore markets is not normative, but useful to understand differences in market views and investor sets.

Large price dislocations in currency forwards have real economic consequences. Hedging for corporates and investors could become prohibitively expensive. As a result, spillovers to other assets can occur. For example, when NDF pricing makes hedging currency risks stemming from local currency bond investments expensive, it can prompt foreign investors to sell bonds.

Asian NDFs have been more volatile on average than corresponding onshore forwards over the period from 2013 to April 2020 (Figure 8). However, the maximum realized volatility was lower in NDFs for the IDR, INR, KRW, and TWD than in the onshore forwards. In crisis episodes, 
including the COVID-19 pandemic, volatility of NDFs tended to increase slightly more than onshore forward volatility (Appendix 1).

Median volatility of Asian NDFs is larger than volatility of onshore deliverable forwards.

\section{Figure 8. Asian FX 1-Month Realized Volatility} (Percent)

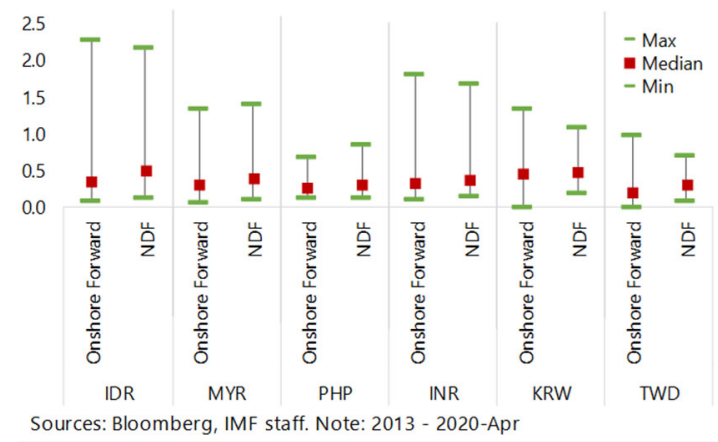

Pricing differentials between onshore and offshore markets can be very large.

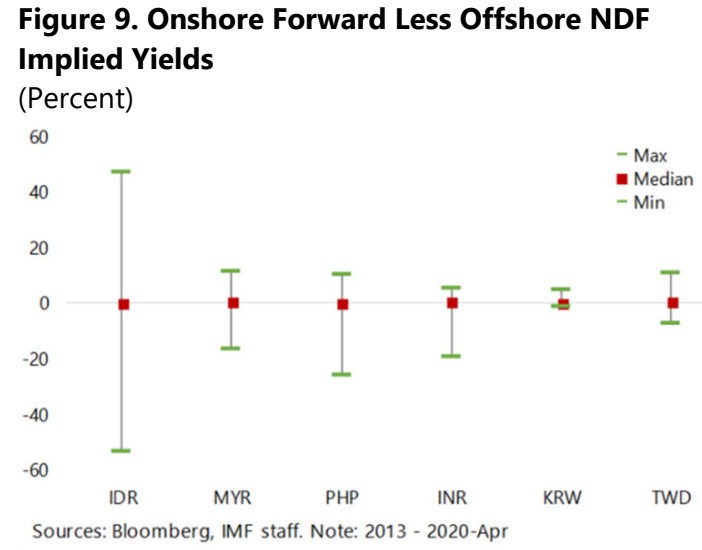

Pricing of onshore forwards and offshore NDFs is primarily based on interest rate parity but prices in both markets can diverge. ${ }^{16}$ Prices in the two markets can differ due to differences in onshore and offshore interest rates, different investor sets, market liquidity, trading hours, counterparty risks, convertibility risks and intervention by the authorities in the domestic forward market. Pricing differences can persist if there are access restrictions to onshore markets that constrain arbitrage between the two markets. Even without restrictions, arbitrage activity may not operate as fully and immediately as in the textbook case due to risk and costly capital (Shleifer \& Vishny 1997).

An intuitive way to look at the pricing of currency forwards is to back out the home currency implied interest rates using covered interest rate parity (CIP). For example, to obtain the KRW interest rate implied in a KRW/USD NDF one would take the NDF price, the spot price, and the US interest rate as given and solve for the KRW interest rate using the standard CIP equation. The higher the implied interest rate for the home currency, the greater is the forward implied currency depreciation for that currency.

The difference in implied interest rates of NDFs and onshore forwards in Asian currencies are close to zero on average (Figure 9) suggesting that deviations are eventually arbitraged. During stress episodes, however, implied interest rates in the onshore and offshore markets have at times differed widely, most notably in Indonesia with interest rate differentials of +/$50 \%$. Substantial pricing deviations also occur in the MYR, PHP, and INR. In these four currencies, deviations are greater to the downside, meaning higher implied interest rates and hence depreciation pressure in the NDF. This asymmetry could be consistent with a stronger reaction to negative news in the NDF or central bank foreign exchange intervention in the

\footnotetext{
${ }^{16}$ Since the GFC, violations of covered interest rate parity in the pricing of forwards are common. See, for example, Du, Tepper, and Verdelhan 2018.
} 
onshore market that cushions depreciation pressures. For the KRW the variation in the implied yield differentials between onshore and offshore markets is close to zero including during stress episodes due to arbitrage between the NDF and onshore markets by Korean banks and investors who are permitted to participate in NDF trading. For the TWD deviations between onshore and offshore implied interest rates are larger than for KRW, but smaller than for the other currencies. This is consistent with partial integration between the TWD onshore and NDF markets which results from Taiwan POC onshore financial institutions being allowed to participate in the NDF market subject to limits (20\% of net open FX positions).

Figures 10 through 15 present the difference in onshore and NDF implied interest rates over time. During the taper tantrum in 2013, large dislocations between onshore and offshore pricing occurred for IDR and INR with the offshore markets pricing large depreciations. At that time, Indonesia and India were viewed as particularly vulnerable to rising US interest rates. ${ }^{17}$ Following the taper tantrum, IDR offshore interest rates collapsed relative to onshore rates as international investors positioned for a rebound in IDR assets. Besides IDR and INR, the taper tantrum affected TWD offshore/onshore pricing, but had relatively little effect on the onshore/offshore pricing differentials of other Asian currencies.

Subsequent emerging market stress episodes include in 2015 a sell-off in EM equities and oil, in 2016 a rapid depreciation of the CNY, and in 2018 a drop in EM equities, oil prices and the CNY. The impact of these episodes on Asian FX markets varied, depending on exposure to the underlying drivers of stresses. The 2015 episode was mostly confined to large price dislocations in the MYR FX space with NDFs first pricing large depreciation relative to onshore forwards and then appreciation. The volatile pattern suggests some overshooting in the NDF market. MYR was exposed during this time to the decline in oil prices since Malaysia is a net energy exporter, unlike the other Asian countries in the sample, and relies to a significant extent on oil and gas revenues for fiscal funding. Implied yield differentials were also volatile following BNM's reinforcement of a ban on MYR NDFs in November 2016. NDFs were pricing substantial depreciation for the IDR and PHP during short episodes in the fall of 2016. This could be related to spillovers from dislocations in the MYR NDF or from concerns over the rapid depreciation of the Chinese yuan. In 2018, the combined shock of EM equity, oil and CNY declines led to some pricing deviations between onshore forwards and NDFs, most notably in the IDR.

In the COVID-19 pandemic, implied interest rates and hence depreciation pressures spiked in the IDR, INR, MYR, and PHP to high levels. Conversely, for the TWD NDF implied interest rates declined far below onshore rates suggesting appreciation pressures in the offshore market. Taiwan POC's successful handling of the COVID-19 pandemic with limited cases and less restrictions than most countries could have contributed to this pattern. In addition, Taiwanese investors, in particular life insurers, have built large overseas portfolios in recent years and

\footnotetext{
${ }^{17}$ During the taper tantrum India and Indonesia were labeled the "fragile five" by Morgan Stanley along with Brazil, South Africa, and Turkey.
} 
increased currency hedges in the NDF market during the crisis could have contributed to lower implied NDF interest rates.

Deviations in Korean won NDF and onshore forward implied interest rates have been limited.

Figure 10. Korean won Onshore Forward Less Offshore NDF Implied Yield (Percent)

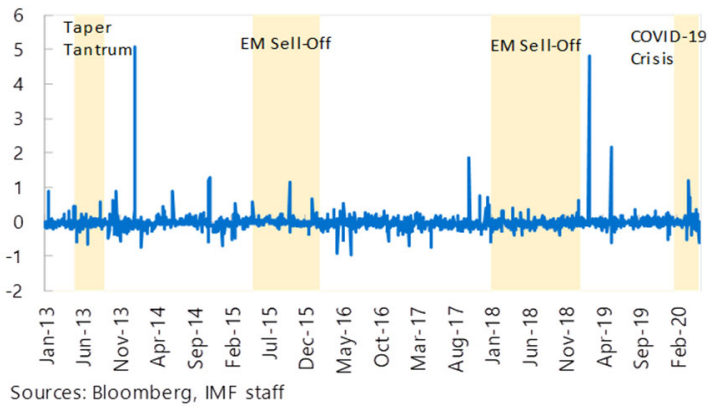

The Indonesian rupiah experienced extreme onshoreoffshore price differentials during the taper tantrum and the COVID-19 pandemic.

Figure 12. Indonesian Rupiah Onshore Forward Less Offshore NDF Implied Yield (Percent)

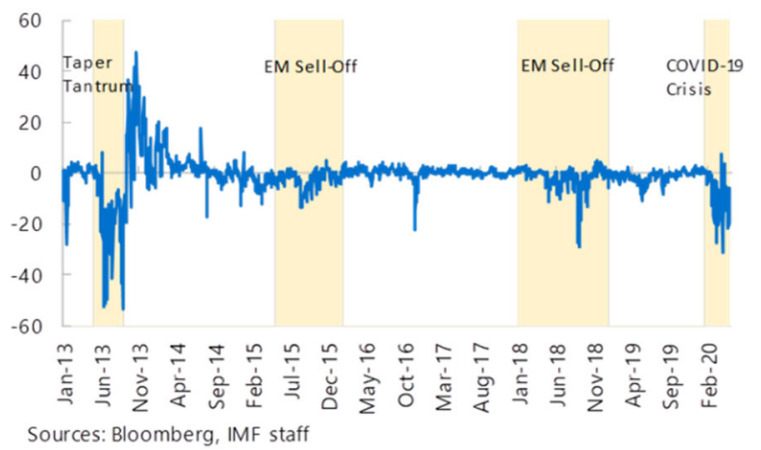

MYR NDFs were stable during the taper tantrum, but pricing was very volatile in 2015 and after the central bank's reinforcement of the NDF ban in November 2016.

Figure 14. Malaysian Ringgit Onshore Forward Less Offshore NDF Implied Yield

(Percent)

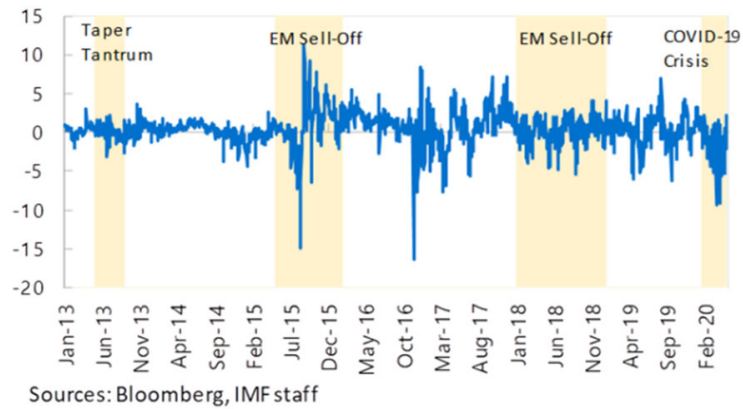

For the New Taiwan dollar there have been more deviations, often with NDF markets pricing more appreciation than onshore markets.

Figure 11. New Taiwan dollar Onshore Forward Less Offshore NDF Implied Yield (Percent)

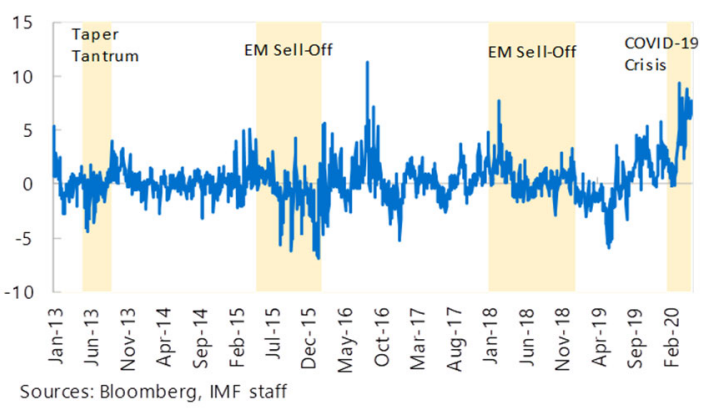

Indian rupee NDFs were pricing much more depreciation in 2013 and during COVID-19 than onshore markets.

Figure 13. Indian Rupee Onshore Forward Less Offshore NDF Implied Yield (Percent)

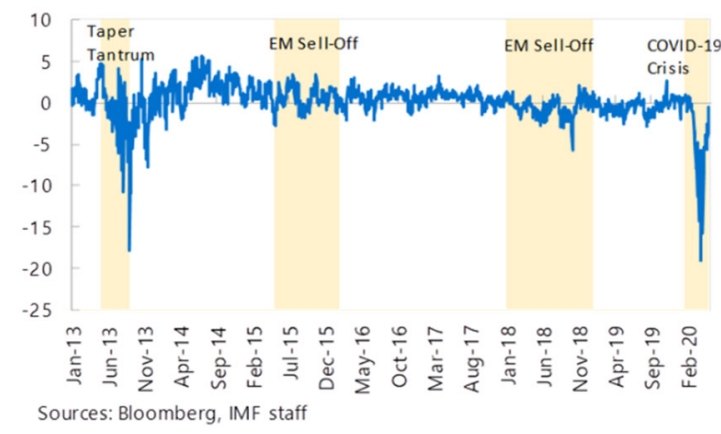

PHP NDF pricing has been fairly close to onshore prices, except in late 2016 and during the COVID-19 pandemic.

Figure 15. Philippine Peso Onshore Forward Less Offshore NDF Implied Yield

(Percent)

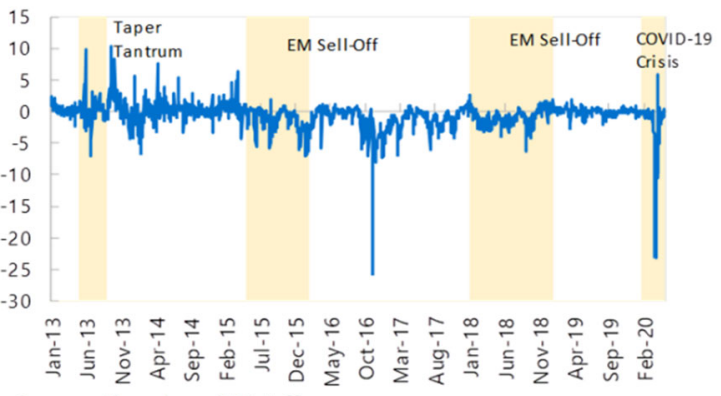

Sources: Bloomberg, IMF staff 


\section{Price Linkages Between Onshore And OfFShore CurRency Markets}

In the previous sections we showed that NDF markets in Asia are large and that NDF pricing can deviate substantially from onshore FX prices indicating some segmentation between the markets. Large NDF volumes do not necessarily mean that NDFs affect onshore pricing. In this section we empirically examine price linkages between NDFs and onshore forward and spot markets using vector error correction models (VECM). We employ Granger causality tests to detect spillovers in returns. In contrast with most existing studies, we time-match NDF and onshore price quotes to control for spillover effects due to differences in trading hours. This allows us to differentiate between time-zone induced and concurrent spillovers. We separately analyze the COVID-19 market stress episode using hourly data.

Results on spillovers between NDFs and onshore markets in the literature are mixed and most studies are dated. For currencies with the largest NDF markets, McCauley, Shu, \& Ma (2014) find two-way spillovers in normal times and one-directional effects from NDFs to onshore markets in crisis periods. Most other studies focus on individual currencies. Reserve Bank of India (2019) finds two-way influences for INR in normal times, and NDF to onshore during crisis episodes. For KRW, Park (2001) finds onshore to NDF spillovers before 1997 and the reverse after. For IDR, Cadarajat and Lubis (2012) find NDF to onshore spillovers. For INR, Misra and Behera (2006) find that onshore markets influence the NDF, Behera (2011) found NDF to onshore spillovers, and Goyal et al. (2013) find a bidirectional relation between onshore and offshore markets that turns unidirectional from NDF to onshore during periods when INR is under depreciation pressure.

\section{A. Empirical Approach and Data}

We analyze the relationship between NDF and onshore markets using VECMs. The VECM approach sheds light on the long-run equilibrium relationship between NDF and onshore markets, the adjustment toward that equilibrium in case of perturbations, and the influence of changes in lags of one variable on the other. For the latter, there is a directional spillover interpretation in the sense of Granger causality. A variable $X$ is said to Granger cause another variable $Y$ if lagged values of $X$ help in predicting $Y$ beyond the information contained in the lagged value $Y$. In other words, we test for lead-lag relationships across variables, while controlling for a variable's own lags and the error correction adjustment to the equilibrium of the variables in levels.

Our dataset covers NDF, spot, and onshore deliverable forward prices for IDR, INR, KRW, MYR, PHP, and TWD extracted from Bloomberg using the BFIX function. We use daily and hourly price data. For NDFs we use both New York end of trading day quotes in line with most other studies, as well as quotes that are exactly time-matched to onshore prices.

We first establish stationarity of the time series using the Augmented Dickey-Fuller (ADF) unit root test. The variables are non-stationary in levels but are stationary in their first differences. 
Second we perform Johansen cointegration tests with lag selection using the Schwarz' Bayesian Information Criterion. We find cointegrating relationships (common long-term trend) for NDFs with spot and onshore deliverable forwards, respectively, for all currencies. Next, given cointegration, we estimate vector error correction models. The estimated cointegrating coefficients from a regression in levels are close to one, pointing to the existence of a longrun equilibrium relation between NDFs and onshore FX markets where prices in both markets are close to equal. To evaluate the short-run properties of the cointegrated series we estimate:

$$
\begin{aligned}
& \Delta S_{t}=\mu_{S}+\gamma_{S}\left(S_{t-1}-\theta_{0}-\theta_{1} F_{t-1}\right)+\sum_{i=1}^{n} \alpha_{S i} \Delta S_{t-i}+\sum_{i=1}^{n} \beta_{S i} \Delta F_{t-i}+\varepsilon_{S_{t}} \\
& \Delta F_{t}=\mu_{F}+\gamma_{F}\left(S_{t-1}-\theta_{0}-\theta_{1} F_{t-1}\right)+\sum_{i=1}^{n} \alpha_{F i} \Delta F_{t-i}+\sum_{i=1}^{n} \beta_{F i} \Delta S_{t-i}+\varepsilon_{F_{t}}
\end{aligned}
$$

where $S$ is either the logged value of prices of spot or onshore deliverable forwards and $F$ is the logged value of prices of NDFs. Schwarz' Bayesian Information Criterion is employed to select the optimal number of lags of the lagged dependent variable and the lagged independent variable. The expression $\left(S_{t-1}-\theta_{0}-\theta_{1} F_{t-1}\right)$ is the error correction term from estimating the cointegration relationship where both $S$ and $F$ are in log levels and $\theta_{0}$ is an intercept. The coefficients $\gamma_{S}$ and $\gamma_{F}$ on the error correction term measure the response of each variable to deviations from the long-run equilibrium in period t-1. Significant, oppositesigned coefficients on the error correction term indicate that both variables are adjusting back to equilibrium if there has been a perturbation. A clear directional influence from one variable to the other cannot be derived from the coefficients on the error correction term. ${ }^{18}$

The coefficients on the lagged independent variables, $\beta_{S i}$ in equation (1) and $\beta_{F i}$ in equation (2), indicate the impact of changes in the lagged independent variables while controlling for changes in the lagged dependent variables and the error correction adjustment to the longrun equilibrium relationship in levels. We employ joint significance tests on the $\beta$ coefficients to test for Granger causality. There is a clear directional interpretation of the lagged independent variable coefficients in the sense of Granger causality. A rejection of the null hypothesis of no Granger causality in either direction between onshore quotes and NDF suggests two-way spillovers between onshore and offshore currency markets. A rejection of the null hypothesis in one direction implies a one-way spillover.

\footnotetext{
${ }^{18}$ To illustrate this, consider for simplicity the case where $\theta_{0}$ is zero and $\theta_{1}$ is 1 (the actual coefficients in our data are close to this case). Then $S_{t-1}-F_{t-1}=e_{t-1}$, where $e_{t-1}$ is the deviation from the long-run equilibrium at time t-1 (error correction term). The error correction term is a function of both $S_{t-1}$ and $F_{t-1}$. It follows that the coefficient on the error correction term in equations (1) and (2), $\gamma$, could be driven by a perturbation to $S_{t-1}$ or $F_{t-1}$ or both.
} 


\section{B. Results}

NDFs and onshore forward and spot exchange rates are linked in long-run equilibrium relationships, as one would expect with at least partial market integration. Appendix 2 shows estimates for the long-run cointegration regressions in levels. Most intercepts are close to zero while the coefficients on the dependent variables are close to one, suggesting that onshore and offshore prices are close to equal in the long run. For most cases, adjustment to deviations from the long-run equilibrium, the coefficient on the error correction term in equations (1) and (2), is statistically significant with the right sign (i.e. converging to equilibrium). There are two exceptions. For MYR, the coefficients on the error correction term in the regressions with NDFs as dependent variable are statistically indistinguishable from zero. Similarly, for INR the error correction term coefficients for NDFs are also statistically insignificant in some cases. See Appendix 3 for coefficient estimates.

Turning to the coefficients on the lagged independent variables, we first analyze the direction of influence between onshore prices at the local market closing time and NDFs at the New York close. In all cases we find that changes in NDF prices granger cause changes in onshore spot and forward FX prices (Table 1). ${ }^{19}$ The relation is one-directional from NDF prices to spot prices for IDR, KRW, PHP, and TWD, and to onshore forward prices for IDR, MYR, and PHP. Two-way influences between NDFs and onshore FX are present for INR (spot and forward), MYR (spot), and TWD (forward).

One-directional influences without controlling for time differences are not surprising. ${ }^{20} \mathrm{New}$ information released during the European and New York trading hours will be priced into NDFs in London or New York when Asian markets are closed. This information will be reflected in Asian markets the following trading day. As a result, there will be a significant impact from the NDF on onshore FX prices simply because the same information is priced in at different times. This is of interest to market participants and policy makers to understand currency dynamics and when deciding on market structure features such as trading hours. However, it is not necessarily evidence that price discovery takes place to a greater extent in one market than the other.

To study whether offshore or onshore markets lead in price discovery, we need to compare NDF quotes with onshore FX quotes at the same time. We present the results in Table 2. For most currencies we now find bi-directional influences between NDFs and onshore markets based on the lagged independent variables. Price discovery in both markets influences the other. There are three exceptions. First, for the KRW there is only a one-directional relation from NDFs to onshore forwards. This is unsurprising given the close integration of the NDF and onshore forward market for KRW (which results in a large coefficient on the error

\footnotetext{
${ }^{19}$ One exception are KRW onshore forwards.

${ }^{20}$ Our result of two-way spillovers for INR, in line with the literature, could be due to the Indian trading day having more overlap with the European and US trading day than is the case for East Asia.
} 
correction term) and the role of domestic Korean banks and investors in the KRW NDF market. In other words, the information set of onshore investors is fully present in the KRW NDF market, leaving no residual new information in the onshore forward price discovery. Second, for the MYR the granger causality runs only from onshore forwards to the NDF market. Interestingly, this was the case even before the collapse of NDF markets following Bank Negara Malaysia regulation in 2016. For the MYR onshore spot market, we find a switch in the direction of spillovers with the 2016 Bank Negara Malaysia measures. Before the measures, the direction of influence was from NDF to onshore spot. After the measures, it was from onshore spot to NDF. This underscores the effectiveness of the regulation in moving price discovery onshore. In the case of Malaysia, the spot market result is more important than the forward market result given that the former is much larger. Finally, for TWD we do not find any significant lead-lag relations.

Table 1. Granger Causality Tests for NDFs at New York Close

(Daily data 2012- Apr 2020; NDF quotes at the end of the trading day in New York)

\begin{tabular}{|c|c|c|c|c|c|c|c|}
\multicolumn{1}{c}{} & IDR & \multicolumn{1}{c}{ INR } & KRW & MYR & PHP & TWD & \\
\hline Spot & $\leftarrow$ & $\leftrightarrow$ & $\leftarrow$ & $\leftrightarrow$ & $\leftarrow$ & $\leftarrow$ & NDF.NY \\
\hline Onshore Forward & $\leftarrow$ & $\leftrightarrow$ & $\times$ & $\leftarrow$ & $\leftarrow$ & $\leftrightarrow$ & NDF.NY \\
\hline
\end{tabular}

Sources: Bloomberg; IMF staff.

Note: NDF.NY refers to the NDF price at the end of the trading day in New York. $\leftrightarrow$ indicates two-way causality, $\rightarrow$ indicates influence on the NDF market from either spot or onshore forward, $\leftarrow$ indicates influence on either spot or onshore forward from NDF, $\times$ indicates no relationship. Significance level is $5 \%$. Granger causality tests are based on joint significance of the lagged independent variables in VECM regressions.

Table 2. Granger Causality Tests for NDFs at Asia Trading Hours

(Daily data 2012-Apr 2020; NDF quotes time-matched to onshore quotes)

\begin{tabular}{|c|c|c|c|c|c|c|c|}
\multicolumn{1}{c}{} & IDR & INR & KRW & \multicolumn{2}{c|}{ MYR } & PHP & TWD \\
\hline Spot & $\leftrightarrow$ & $\leftrightarrow$ & $\leftrightarrow$ & $\leftrightarrow$ & $\leftrightarrow$ & $\times$ & NDF \\
\hline Onshore Forward & $\leftrightarrow$ & $\leftrightarrow$ & $\leftarrow$ & $\rightarrow$ & $\leftrightarrow$ & $\times$ & NDF \\
\hline
\end{tabular}

Sources: Bloomberg; IMF staff.

Note: NDF refers to the NDF price at the time of a country's domestic end-of-day trading hours, i.e. the same time as the spot and onshore forward price quotes. $\leftrightarrow$ indicates two-way causality, $\rightarrow$ indicates influence on the NDF market from either spot or onshore forward, $\leftarrow$ indicates influence on either spot or onshore forward from NDF, $\times$ indicates no relationship. Significance level is $5 \%$. Granger causality tests are based on joint significance of the lagged independent variables in VECM regressions.

\section{Price Linkages During the COVID-19 Pandemic}

Price linkages between markets in crisis periods could differ from normal times. The literature finds for the most part that NDF market influence appears to increase in crisis times (Reserve Bank of India 2019 for INR; Cadarajat \& Lubis 2012 for IDR; McCauley, Shu, \& Ma 2014 for EM currencies). 
The analysis of crisis episodes is statistically difficult because of short time series. To analyze spillovers between NDF and onshore FX markets during the COVID-19 crisis (Jan 20 to Apr 30 2020) we use hourly price quotes which gives us sufficient observations. ${ }^{21}$ We match the exact time between NDF and onshore quotes analogous to the results in Table 2 above. This removes any spillovers due to differences in when trading takes place. We are left with concurrent spillovers that are due to one market leading the other in price discovery.

For the error correction term, we find that all coefficients have the expected sign (convergence to equilibrium) and are significant at the 10 percent level except for the error correction term in the IDR NDF regressions (Appendix 4). The lack of convergence to equilibrium for IDR NDFs during COVID-19 is likely due to the large, sustained dislocation between IDR NDF and onshore markets (Figure 12). Looking at the lagged independent variables, we find evidence that during COVID-19 the NDF market led developments in the onshore forward markets for the IDR and the INR (Table 3), both currencies under significant depreciation pressure during the COVID-19 market turmoil. For other currency pairs, there are either bi-directional relations or no association for the high frequency data. TWD is an interesting case with the direction of influence from NDF to spot, but from onshore forward to NDF. ${ }^{22}$

Table 3. Granger Causality Tests During COVID-19

(Hourly data 20 Jan 2020 to 30 Apr 2020; NDF quotes time-matched to onshore quotes)

\begin{tabular}{|c|c|c|c|c|c|c|c|}
\multicolumn{1}{c|}{} & \multicolumn{1}{c}{ IDR } & \multicolumn{1}{c}{ INR } & \multicolumn{1}{c}{ KRW } & MYR & PHP & TWD & \\
\hline Spot & $\leftrightarrow$ & $\leftrightarrow$ & $\times$ & $\times$ & $\times$ & $\leftarrow$ & NDF \\
\hline Onshore Forward & $\leftarrow$ & $\leftarrow$ & $\leftrightarrow$ & $\times$ & $\times$ & $\rightarrow$ & NDF \\
\hline
\end{tabular}

Sources: Bloomberg; IMF staff.

Note: Data is hourly with NDF, spot and onshore forward prices time-matched on an hourly basis. $\leftrightarrow$ indicates two-way causality, $\rightarrow$ indicates influence on the NDF market from either spot or onshore forward, $\leftarrow$ indicates influence on either spot or onshore forward from NDF, $\times$ indicates no relationship. Significance level is $5 \%$. At a $10 \%$ significance level there is no significant spillover from NDF to spot for IDR and from spot to NDF for INR. Granger causality tests are based on joint significance of the lagged independent variables in VECM regressions.

\section{Domestic Non-Deliverable ForWARds (DNDFs)}

Domestic non-deliverable forwards (DNDFs) are net-settled in local currency and traded onshore in the jurisdiction of the issuing country. They are distinct from NDFs which are typically settled in USD and trade offshore. They are also distinct from deliverable onshore forwards for which the entire notional amount is exchanged on the due date and not just the

\footnotetext{
${ }^{21}$ To our knowledge, we are the first to move to higher frequency data than daily to analyze NDF and onshore market relationships.

${ }^{22}$ For the 2015/16 and 2018 EM sell-off episodes we also find some evidence for one-way spillovers from NDFs to onshore markets, but many results are not statistically significant.
} 
profit or loss (net settlement). DNDFs were pioneered and extensively used by the Brazilian central bank for intervention purposes (Garcia and Volpon 2014). In Asia, DNDFs are only used in volume in Indonesia as a monetary policy tool while secondary market trading is in the development stage. In the Philippines, the central bank maintains a little-used DNDF facility.

Motives for central banks to create DNDFs include (1) intervention without affecting foreign exchange reserves (since DNDFs are settled in local currency, a short USD exposure on DNDFs does not imply a USD liability on the issuing central bank's balance sheet); (2) DNDFs can help dampen spot or deliverable forward demand for USD by providing banks another option to cover market risk from short USD positions; (3) provide another FX intervention tool with which the central bank can set price signals.

Although DNDFs do not count against central banks' foreign exchange reserves, large short USD DNDF positions can be risky for the central bank. If counterparties choose to not roll over DNDF positions at maturity and instead demand USD in the spot or deliverable forward market, depreciation pressures can be exacerbated. Losses on DNDFs can impair central banks' capital. For banks, investors, and corporates, DNDFs may not be perfect substitutes for deliverable instruments or NDFs. For example, corporates may have an actual USD demand in the future and therefore prefer currency delivery. Convertibility risk is a concern given that DNDFs are settled in domestic currency at maturity. In the case of Brazil, concerns about convertibility during stress episodes led to large discounts on DNDFs relative to NDFs (Garcia and Volpon 2014).

Bank Indonesia (BI) introduced IDR net settled DNDFs in November 2018 to ease pressures on the rupiah by providing an alternative hedging instrument. ${ }^{23}$ Currently, DNDF transactions largely happen in the primary market, with $\mathrm{BI}$ offering 1 and 3-month DNDFs daily. ${ }^{24}$ Most transactions take place at the 1-month tenor. BI's counterparties for DNDFs are mostly domestic banks and offshore subsidiaries of global banks with a presence in Indonesia. Poor secondary market liquidity contributes to limited use of DNDFs by corporates and foreign investors. In addition, for foreign investors the requirement of an underlying hedging need makes DNDFs less attractive than NDFs. ${ }^{25}$

We estimate that outstanding DNDFs auctioned by BI were in the range of USD1 to 4 bn prior to COVID-19. Starting in February 2020 when Indonesia experienced large portfolio outflows and IDR depreciation pressures, BI increased sales of DNDFs to close to USD 8 bn (Figure 16). This compares to net portfolio outflows of USD 2.4 bn in February and USD 7.9 bn in March.

\footnotetext{
${ }^{23}$ DNDFs could also help reduce selling pressure by foreign investors in the bond market. As shown in section IV, NDF implied interest rates tend to spike in stress episodes which makes hedging of currency risk for bond investors expensive, in turn leading them to liquidate bond positions.

24 The 3-month contract was introduced in February 2019.

25 The underlying asset requirement for DNDF use was waived for transaction below USD 5mn in April 2019.
} 
DNDF transactions have largely moved in tandem with the rupiah exchange rate, rising when the rupiah is under depreciation pressure.

\section{DNDF transaction volumes increased during COVID-19.}

Figure 16. Indonesia Domestic NDF

(Billions of US Dollars and Exchange Rate)

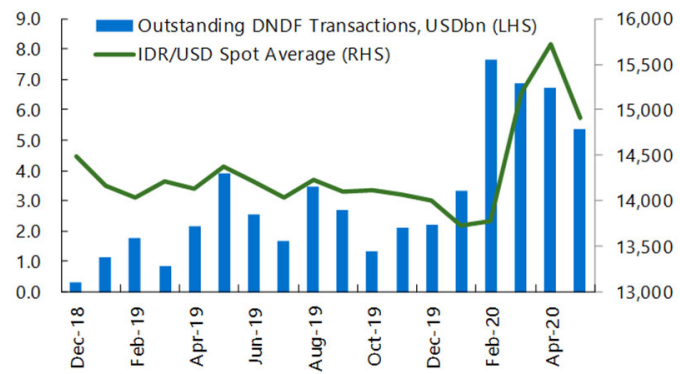

Sources: Bloomberg, Bank Indonesia, IMF staff. Note: As of mid-May
DNDFs tend to price in less depreciation than NDFs when the rupiah faces depreciation pressures.

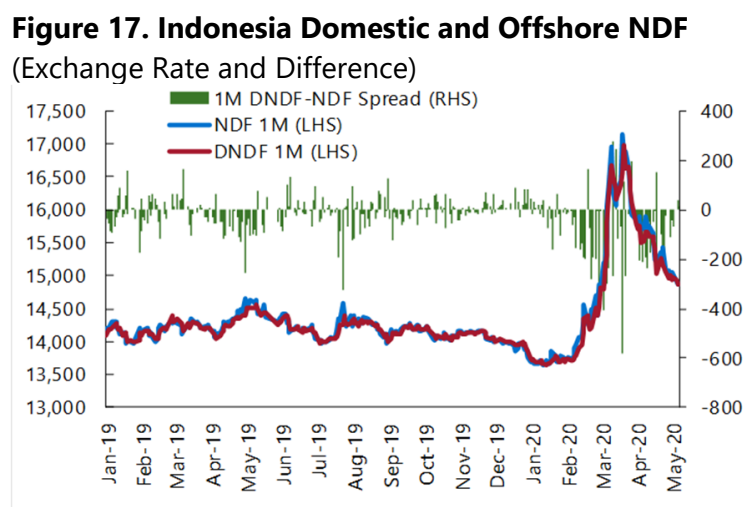

Sources: Bloomberg, Bank Indonesia, IMF staff

The IDR rate in the DNDF market is fixed by BI using the Jakarta Interbank Spot Dollar Rate daily and has typically been below that in the NDF market. The spread was the widest when the IDR came under depreciation pressure in mid-May and early August 2019 amid the escalation in US-China trade tensions. During the COVID-19 market turbulence the DNDF NDF spread reached record levels with the NDF market pricing more depreciation (Figure 17). Interestingly, while DNDFs priced less depreciation than NDFs they were pricing more depreciation than onshore deliverable forwards (Figures 18 and 19), suggesting that BI may have set DNDF pricing to bridge between NDF and onshore deliverable forward markets. Market contacts argue that DNDFs helped reduce depreciation pressure on the IDR spot rate in stress episodes by absorbing some USD demand. Relative to the IDR NDF market, the DNDF remains small and there has not been a significant move of trading volume from the NDF market to DNDFs so far. That said, the IDR DNDF remains in the early development stages and $\mathrm{BI}$ has made efforts in 2020 to increase DNDF liquidity including by expanding the types of underlying transactions that are eligible for DNDF positions and allowing banks to include DNDFs as part of their net open FX position calculation.

Prior to COVID-19, deliverable onshore forwards, NDFs, and DNDFs were priced close to each other.

Figure 18. IDR forward curves on 27 Dec 2019

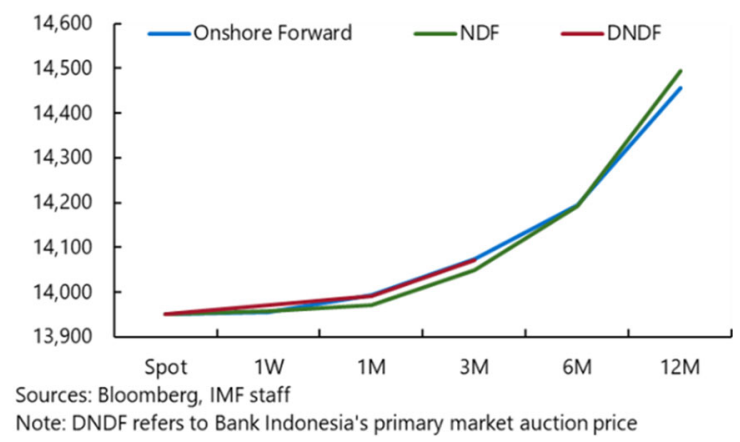

During the COVID-19 market stress, NDFs priced more depreciation than onshore forwards and DNDFs.

Figure 19. IDR forward curves on 20 Mar 2020

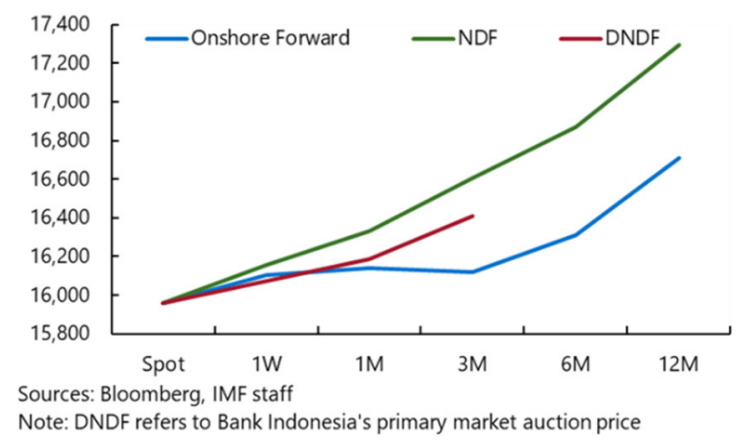


The Philippines' central bank (BSP) offers a DNDF-like standing facility. The Currency Rate Risk Protection Program (CRRP) facility offers non-deliverable forward contracts net settled in pesos to domestic banks. Banks act as an intermediary for customers with hedging needs arising from eligible foreign currency obligations. The CRRP was reactivated in September 2018, but the facility was first introduced in 1997 during the Asian Financial Crisis and last utilized in 2009. The intent of the CRRP is to serve as a hedging facility that prevents corporates, notably importers, from buying USD on the spot market for future requirements, in turn reducing depreciation pressures on the peso. BSP sets DNDF prices based on interest parity, which could make DNDFs attractive relative to NDFs when there are depreciation pressures. The size of outstanding transactions is unknown, but uptake has been very limited according to market contacts.

\section{Conclusion}

NDF markets in major Asian currencies are large, often with higher trading volumes than onshore FX markets. NDFs tend to be more volatile than their onshore counterparts. During market stress periods including the COVID-19 pandemic, pricing of NDFs often diverges from onshore FX markets. In most cases NDFs price more depreciation than onshore markets in the initial phases of markets stress. The sometimes very large deviations in NDF pricing can have consequences for the real economy and nonresident holdings of local currency assets by making hedging expensive.

Spillovers from NDF markets and associated loss of control are a concern among policymakers in many emerging markets. We find long-term equilibrium relationships between NDFs and onshore markets and, in most cases, both NDFs and onshore markets adjust back toward the long-term equilibrium in case of perturbations. Additionally, we find that changes in NDF prices affect onshore FX markets and vice versa. We show that the finding of one-way influence from NDFs to onshore markets as in some other studies, for example McCauley, Shu and Ma 2014, results from using NDF quotes from a time zone outside of Asian trading hours. In that case, NDFs appear to lead onshore markets because they price new information when onshore markets were closed. During the COVID-19 market stress, we find some evidence for greater one-directional influence from NDF to onshore for the Indonesia rupiah and the Indian rupee.

Policymakers' approaches to NDF markets in Asia vary. Korea embraced NDFs by allowing domestic financial institutions to participate. As a result, the KRW NDF and onshore markets are closely integrated. In contrast, Malaysia enforced regulation to limit MYR NDF trading and took measures to deepen onshore FX markets. China is following yet another path with the offshore deliverable CNH market. Indonesia introduced a domestic local currency settled NDF. Different policy approaches reflect country specific circumstances and preferences. Policymakers have to make tradeoffs involving many different aspects including control, market depth, spillovers, attractiveness to nonresident investors, real economy impacts and prudential considerations. For most emerging market currencies NDF markets are likely to continue to flourish as long as full convertibility is not established. 


\section{References}

Behera, H. K. (2011). Onshore and offshore market for Indian rupee: recent evidence on volatility and shock spillover. Macroeconomics and Finance in Emerging Market Economies, 4(1), 43-55.

BIS (2019). Triennial Central Bank Survey of Foreign Exchange and Over-the-counter (OTC) Derivatives Markets in 2019.

Cadarajat, Y. \& Lubis, A. (2012). Offshore and onshore IDR market: an evidence on information spillover. Bulletin of Monetary Economics and Banking, April, pp 323-47.

Du, W., Tepper, A., \& Verdelhan, A. (2018). Deviations from covered interest rate parity. The Journal of Finance, 73(3), 915-957.

Garcia, M., \& Volpon, T. (2014). DNDFs: a more efficient way to intervene in FX markets? (Texto para discussão, No. 621, Pontifícia Universidade Católica do Rio de Janeiro (PUC-Rio), Departamento de Economia, Rio de Janeiro.

Goyal, R., R. Jain \& S. Tewari (2013). Non deliverable forward and onshore Indian rupee market: a study on inter-linkages. Reserve Bank of India Working Paper Series, 11/2013, December.

Granger, C. W. (1969). Investigating causal relations by econometric models and crossspectral methods. Econometrica, 424-438.

International Monetary Fund (2019). Malaysia: Staff Report for the 2019 Article IV Consultation. IMF Country Report No. 19/71

International Monetary Fund (2020). Malaysia: Staff Report for the 2020 Article IV Consultation. IMF Country Report No. 20/57

Ishii, S., Ötker-Robe, I., \& Cui, L. (2001). Measures to limit the offshore use of currencies: pros and cons. International Monetary Fund WP/01/43.

Ma, G., Ho, C., \& McCauley, R. N. (2004). The markets for non-deliverable forwards in Asian currencies. BIS Quarterly Review, June.

McCauley, R. N., Shu, C., \& Ma, G. (2014). Non-deliverable forwards: 2013 and beyond. BIS Quarterly Review, March.

McCauley, R. N., \& Shu, C. (2016). Non-deliverable forwards: impact of currency internationalisation and derivatives reform. BIS Quarterly Review December. 
McCauley, R. N., \& Shu, C. (2019). Recent renminbi policy and currency comovements. Journal of International Money and Finance, 95, 444-456.

Misra, S., \& Behera, H. (2006). Non deliverable foreign exchange forward market: An overview. Reserve Bank of India Occasional Papers, 27(3), 25-55.

Packer, F., A. Schrimpf and V. Sushko (2019): "Renminbi turnover tilts onshore", BIS Quarterly Review, December.

Park, J. (2001). Information flows between non-deliverable forward (NDF) and spot markets: Evidence from Korean currency. Pacific-Basin Finance Journal, 9(4), 363-377.

Patel, N., \& Xia, F. D. (2019). Offshore markets drive trading of emerging market currencies. BIS Quarterly Review, December.

RBI Reserve Bank of India (2019). Report of the task force on offshore rupee markets, July.

Shleifer, A., \& Vishny, R. W. (1997). The limits of arbitrage. The Journal of Finance, 52(1), 3555. 


\section{Appendix 1: Realized volatility of onshore forwards and NDFs}

\begin{tabular}{|c|c|c|c|c|c|c|c|c|c|c|c|c|c|}
\hline \multirow[t]{2}{*}{ Period } & & & \multicolumn{3}{|c|}{ MYR } & \multirow{2}{*}{$\begin{array}{c}\text { PHP } \\
\text { Onshore } \\
\text { Forward }\end{array}$} & \multicolumn{3}{|c|}{ INR } & \multicolumn{2}{|l|}{ KRW } & \multicolumn{2}{|l|}{ TWD } \\
\hline & & $\begin{array}{l}\text { Onshore } \\
\text { Forward }\end{array}$ & NDF & $\begin{array}{l}\text { Onshore } \\
\text { Forward }\end{array}$ & NDF & & NDF & $\begin{array}{l}\text { Onshore } \\
\text { Forward }\end{array}$ & NDF & $\begin{array}{l}\text { Onshore } \\
\text { Forward }\end{array}$ & NDF & $\begin{array}{l}\text { Onshore } \\
\text { Forward }\end{array}$ & NDF \\
\hline Taper Tantrum & $\begin{array}{l}\text { May } 13- \\
\text { Aug } 13\end{array}$ & 0.45 & 0.75 & 0.47 & 0.52 & 0.37 & 0.43 & 0.62 & 0.75 & 0.52 & 0.51 & 0.28 & 0.34 \\
\hline EM Sell Off (1) & $\begin{array}{c}\text { May } 15 \text { - } \\
\text { Jan } 16\end{array}$ & 0.43 & 0.66 & 0.62 & 0.71 & 0.25 & 0.32 & 0.32 & 0.36 & 0.56 & 0.53 & 0.33 & 0.42 \\
\hline $\begin{array}{c}\text { China Slowdown/ } \\
\text { RMB Weakness }\end{array}$ & $\begin{array}{l}\text { Feb } 16- \\
\text { Dec } 16\end{array}$ & 0.41 & 0.60 & 0.56 & 0.76 & 0.30 & 0.40 & 0.27 & 0.35 & 0.64 & 0.63 & 0.27 & 0.46 \\
\hline EM Sell Off (2) & $\begin{array}{l}\text { Jan } 18- \\
\text { Dec } 18\end{array}$ & 0.30 & 0.52 & 0.19 & 0.34 & 0.24 & 0.34 & 0.37 & 0.41 & 0.44 & 0.49 & 0.19 & 0.31 \\
\hline COVID-19 & $\begin{array}{l}\text { Jan } 20- \\
\text { Apr } 20\end{array}$ & 0.62 & 1.09 & 0.39 & 0.59 & 0.26 & 0.33 & 0.37 & 0.52 & 0.66 & 0.61 & 0.26 & 0.35 \\
\hline $\begin{array}{c}\text { Entire Sample } \\
\text { Period }\end{array}$ & $\begin{array}{l}2013- \\
\text { Apr-20 }\end{array}$ & 0.35 & 0.51 & 0.30 & 0.39 & 0.27 & 0.32 & 0.32 & 0.38 & 0.46 & 0.48 & 0.20 & 0.30 \\
\hline
\end{tabular}

Sources: Bloomberg, IMF staff estimates.

\section{Appendix 2: Coefficients and intercepts for the long-run cointegration regressions}

\begin{tabular}{c|c|c|c|c|}
\multicolumn{5}{c}{ Spot, NDF } \\
\cline { 2 - 5 } & Coefficients & Standard Errors & Intercepts & Standard Errors \\
\hline IDR & 0.9933 & 0.0017 & 0.0473 & 0.0165 \\
INR & 1.0169 & 0.0010 & -0.0850 & 0.0043 \\
KRW & 1.0167 & 0.0029 & -0.1186 & 0.0202 \\
MYR & 1.0096 & 0.0005 & -0.0165 & 0.0006 \\
PHP & 0.9647 & 0.0014 & 0.1313 & 0.0054 \\
TWD & 0.9583 & 0.0085 & 0.1449 & 0.0289 \\
\hline
\end{tabular}

\begin{tabular}{|c|c|c|c|c|}
\multicolumn{5}{c}{ Onshore Forward, NDF } \\
\cline { 2 - 5 } & Coefficients & Standard Errors & Intercepts & Standard Errors \\
\hline IDR & 0.9971 & 0.0014 & 0.0246 & 0.0136 \\
INR & 0.9882 & 0.0008 & 0.0499 & 0.0032 \\
KRW & 0.9994 & 0.0009 & 0.0040 & 0.0063 \\
MYR & 0.9993 & 0.0004 & 0.0018 & 0.0005 \\
PHP & 0.9784 & 0.0011 & 0.0821 & 0.0044 \\
TWD & 0.8967 & 0.0095 & 0.3492 & 0.0323 \\
\hline
\end{tabular}

Spot, NDF.NY

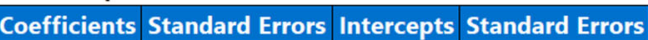

\begin{tabular}{l|l} 
IDR \\
INR \\
KRW \\
MYR \\
PHP \\
TWD
\end{tabular}

\begin{tabular}{|l|l|l|l|}
\hline 0.9931 & 0.0018 & 0.0491 & 0.0170 \\
\hline 1.0158 & 0.0012 & -0.0803 & 0.0052 \\
\hline 1.0149 & 0.0034 & -0.1063 & 0.0238 \\
\hline 1.0087 & 0.0008 & -0.0152 & 0.0010 \\
\hline 0.9639 & 0.0014 & 0.1347 & 0.0056 \\
\hline 0.9415 & 0.0035 & 0.2043 & 0.0118 \\
\hline
\end{tabular}

\begin{tabular}{|l} 
IDR \\
INR \\
KRW \\
MYR \\
PHP \\
TWD
\end{tabular}

Onshore Forward, NDF.NY \begin{tabular}{|l|l|l|l|}
\hline Coefficients & Standard Errors & Intercepts & Standard Errors \\
\hline
\end{tabular}

Note: Presented results are from regressions in log levels of (1) spot on NDF (local time); (2) onshore forward on NDF (local Asia time);

(3) spot on NDF at NY close; (4) onshore forward on NDF at NY close. All regressions include an intercept.

Source: IMF staff estimates. 


\section{Appendix 3: Coefficients on error correction terms; daily data}

Period: 2012 - Apr 2020

\begin{tabular}{c|c|c|c|c|}
\multicolumn{2}{c}{ Coefficients } & \multicolumn{2}{c}{ Standard Errors } \\
\cline { 2 - 5 } & Spot & NDF.NY & Spot & NDF.NY \\
\hline IDR & -0.0608 & 0.0523 & 0.0100 & 0.0149 \\
INR & -0.0400 & 0.0545 & 0.0215 & 0.0267 \\
\cline { 2 - 5 } KRW & -0.1934 & 0.1126 & 0.0303 & 0.0345 \\
\cline { 2 - 5 } MYR & -0.3077 & -0.0165 & 0.0300 & 0.0454 \\
PHP & -0.2411 & 0.1823 & 0.0225 & 0.0263 \\
TWD & -0.2068 & 0.1218 & 0.0197 & 0.0270 \\
\hline
\end{tabular}

\begin{tabular}{|c|c|c|c|}
\multicolumn{2}{c}{ Coefficients } & \multicolumn{2}{c|}{ Standard Errors } \\
\hline Onshore Forward & NDF.NY & Onshore Forward & NDF.NY \\
\hline-0.1195 & 0.0719 & 0.0152 & 0.0196 \\
\hline-0.0746 & 0.0679 & 0.0289 & 0.0363 \\
\hline-0.7411 & 0.2536 & 0.0345 & 0.0402 \\
\hline-0.3232 & 0.0255 & 0.0335 & 0.0505 \\
\hline-0.2575 & 0.2077 & 0.0254 & 0.0299 \\
\hline-0.1556 & 0.1214 & 0.0157 & 0.0202 \\
\hline \multicolumn{2}{|c|}{ Coefficients } & \multicolumn{3}{|c|}{ Standard Errors } \\
\hline
\end{tabular}

\begin{tabular}{|c|c|c|c|c|}
\cline { 2 - 5 } & \multicolumn{2}{c}{ Coefficients } & \multicolumn{2}{c|}{ Standard Errors } \\
\cline { 2 - 5 } IDR & Spot & NDF & Spot & NDF \\
\cline { 2 - 5 } INR & -0.0511 & 0.0472 & 0.0107 & 0.0149 \\
\cline { 2 - 5 } KRW & 0.0112 & 0.0430 & 0.0244 & 0.0260 \\
MYR & -0.0945 & 0.1505 & 0.0367 & 0.0368 \\
PHP & -0.1493 & -0.0006 & 0.0378 & 0.0424 \\
TWD & -0.1988 & 0.1959 & 0.0234 & 0.0252 \\
\hline
\end{tabular}

\begin{tabular}{|c|c|c|c|}
\hline Onshore Forward & NDF & Onshore Forward & NDF \\
\hline-0.0918 & 0.0660 & 0.0165 & 0.0197 \\
\hline-0.0061 & 0.0404 & 0.0337 & 0.0362 \\
\hline-0.6206 & 0.3815 & 0.1168 & 0.1165 \\
\hline-0.1418 & 0.0043 & 0.0462 & 0.0512 \\
\hline-0.1646 & 0.1756 & 0.0293 & 0.0318 \\
\hline-0.2089 & 0.1757 & 0.0272 & 0.0357 \\
\hline
\end{tabular}

Note: Coefficients are $\gamma$ from equations (1) and (2) in section V. Column headings (spot/NDF.NY/NDF) identify the dependent variable. NDF.NY is the NDF quote at the New York close. NDF is the NDF quote at local Asia time.

Source: IMF staff estimates.

\section{Appendix 4: Coefficients on error correction terms; hourly data}

Period: 20 Jan 2020 to 30 Apr 2020

\begin{tabular}{|c|c|c|c|c|c|c|c|c|}
\hline & \multicolumn{2}{|c|}{ Coefficients } & \multicolumn{2}{|c|}{ Standard Errors } & \multicolumn{2}{|c|}{ Coefficients } & \multicolumn{2}{|c|}{ Standard Errors } \\
\hline & Spot & NDF & Spot & NDF & Onshore Forward & NDF & Onshore Forward & NDF \\
\hline IDR & -0.0914 & 0.0167 & 0.0130 & 0.0181 & -0.0902 & 0.0185 & 0.0126 & 0.0177 \\
\hline INR & -0.1163 & 0.0767 & 0.0215 & 0.0290 & -0.1366 & 0.0978 & 0.0216 & 0.0300 \\
\hline KRW & -0.3698 & 0.2349 & 0.0487 & 0.0467 & -0.6011 & 0.1820 & 0.0963 & 0.0993 \\
\hline MYR & -0.1817 & 0.1760 & 0.0204 & 0.0253 & -0.2112 & 0.1665 & 0.0229 & 0.0282 \\
\hline PHP & -0.1297 & 0.0671 & 0.0264 & 0.0323 & -0.2406 & 0.0876 & 0.0357 & 0.0433 \\
\hline TWD & -0.0514 & 0.0932 & 0.0178 & 0.0206 & -0.0653 & 0.1015 & 0.0178 & 0.0221 \\
\hline
\end{tabular}

Note: Coefficients are $\gamma$ from equations (1) and (2) in section V. Column headings (spot/NDF.NY/NDF) identify the dependent variable. NDF is the NDF quote at local Asia time.

Source: IMF staff estimates. 